\title{
The 2014 Hajj and Umrah - current recommendations
}

Eurosurveillance editorial team (eurosurveillance@ecdc.europa.eu) ${ }^{1}$

1. European Centre for Disease Prevention and Control (ECDC) Stockholm, Sweden

Citation style for this article:

Eurosurveillance editorial team. The $2014 \mathrm{Hajj}$ and Umrah - current recommendations. Euro Surveill. 2014;19(23):pii=20826. Available online: http://www. eurosurveillance.org/ViewArticle.aspx?Articleld $=20826$

published on 12 June 2014

This year, the Hajj - the annual pilgrimage to Mecca, Saudi Arabia - will take place approximately during 2-7 October 2014. Umrah is a similar pilgrimage, but it can be undertaken any time during the year. In 2014, it is expected that the Ramadan period, approximately between 28 June and 28 July, will attract the largest number of Umrah pilgrims.

The congregation of so many people from different parts of the world in crowded conditions within a confined area for a short period of time presents many public health challenges. About three million pilgrims attend the Hajj every year. They travel to Saudi Arabia from more than 180 different countries, of which some 45,000 travel from the European Union (EU) and European Economic Area (EEA).

As the reported number of human cases of Middle East respiratory syndrome coronavirus (MERS-CoV) infection in the Arabian Peninsula has increased rapidly in the past months, several organisations have issued travel advice specifically related to MERS-CoV, in addition to the general Hajj and Umrah travel advice published every year. On 3 June, the World Health Organization (WHO) published travel advice on MERSCoV for pilgrimages and actions for countries to take in preparation for, during and after Umrah and Hajj [1].

The United States Centers for Disease Control and Prevention (CDC) published advice on what travellers can do to protect themselves from MERS-CoV on 4 June [2]. The CDC reiterates the WHO recommendations and makes further reference to the Saudi Arabian Ministry of Health recommendation [3] that some groups should postpone travel.

The European Centre for Disease Prevention and Control (ECDC) published an updated risk assessment on 31 May, which also contains recommendations for travellers [4].

\section{References}

1. World Health Organization (WHO). World - travel advice on MERS-CoV for pilgrimages. Geneva: WHO; Jun 2014. Available from: http://www.who.int/ith/updates/20140603/en/

2. Centers for Disease Control and Prevention (CDC). Hajj and Umrah in Saudi Arabia. Atlanta: CDC; Jun 2014. Available from: http://wwwnc.cdc.gov/travel/notices/alert/ hajj-umrah-saudi-arabia

3. Memish ZA, Al Rabeeah AA. Health conditions for travellers to Saudi Arabia for the Umra and pilgrimage to Mecca (Haji) 2014. J Epidemiol Glob Health. 2014;4(2):73-5.

4. European Centre for Disease Prevention and Control (ECDC). Updated rapid risk assessment. Severe respiratory disease associated with Middle East respiratory syndrome coronavirus (MERS-CoV), Tenth update, 31 May 2014. Stockholm: ECDC; May 2014. Available from: http://www.ecdc.europa.eu/en/ publications/Publications/RRA-Middle-East-respiratorysyndrome-coronavirus-update10.pdf 